\title{
Association of Single-Nucleotide Polymorphisms of MAFB Gene with Nonsyndromic Cleft Lip with or without Cleft Palate in Kinh Vietnamese Patients
}

\author{
Hoanh Duy Ba Phan ${ }^{1}$ Lam Hoai Phuong ${ }^{1}$ Hoang Anh Vu \\ ${ }^{1}$ Department of Oral and Maxillofacial Surgery, University Medical \\ Address for correspondence Hoang Anh Vu, MD, PhD, Center for \\ Center, Ho Chi Minh City, Vietnam \\ 2 Center for Molecular Biomedicine, University of Medicine and \\ Pharmacy, Ho Chi Minh City, Vietnam \\ Molecular Biomedicine, University of Medicine and Pharmacy at Ho \\ Chi Minh City, 217 Hong Bang Street, District 5, Ho Chi Minh City \\ 700000, Vietnam (e-mail: hoanganhvu@ump.edu.vn).
}

Indian J Plast Surg 2022;55:70-74.

\begin{abstract}
Background Cleft lip with or without palate $(\mathrm{CL} / \mathrm{P})$ is the most common orofacial birth defect. Single-nucleotide polymorphisms (SNPs) in MAFB gene (V-Maf avian musculoaponeurotic fibrosarcoma oncogene homolog $B$ ) were identified as susceptible to this defect in a genome-wide association study. To further evaluate its role in this birth defect, we conducted this study with the aim of identifying allele frequencies, genotype frequencies, and association of SNPs rs13041247, rs6065259, and rs6072081 of MAFB gene with nonsyndromic cleft lip/palate (NCL/P) in Kinh Vietnamese patients.

Methods We performed case-control study involved 79 patients with NCL/P and 77 healthy controls. DNAs were extracted from participants' saliva and tetra-amplification refractory mutation system polymerase chain reaction (tetra-ARMS PCR) was used for genotyping SNPs.

Results SNPs of MAFB gene were genotyped using the Tetra-ARMS PCR method. We found that genotype CT of rs 13041247 was associated with an increased risk of NCL/P in Kinh Vietnamese (odds ratio $\mathrm{TCTT}_{\mathrm{T}}\left[\mathrm{OR}_{\mathrm{TC} / \mathrm{TT}}\right]=1.63,95 \%$ confidence interval $[\mathrm{Cl}]$ $=0.83-3.19, p=0.17)$. The $G$ allele genotypes of SNP rs6072081 increase high risk for the malformation, statistically significant result $\left(\mathrm{OR}_{\mathrm{GG} / \mathrm{AA}}=7.06,95 \% \mathrm{Cl}=2.13-\right.$ 23.42, $p<0.001)$. There is no clear association between rs6065259 and $\mathrm{CL} / \mathrm{P}$

Keywords

- cleft lip

- MAFB

- SNPS

- Vietnamese $\left(\mathrm{OR}_{\mathrm{AA} / \mathrm{GG}}=0.75,95 \% \mathrm{Cl}=0.22-2.50, p=0.32 ; \mathrm{OR}_{\mathrm{AG} / \mathrm{GG}}=1.53,95 \% \mathrm{Cl}=0.79-2.97\right.$, $p=0.32$ ). When the patients were divided into the phenotypic subgroups, there was a similar significant trend between the patients and controls for all SNPs.

Conclusions Our study provides further evidence of role of MAFB gene variations with NCL/P defect in Kinh Vietnamese.
\end{abstract}

\section{Introduction}

Cleft lip with or without palate $(\mathrm{CL} / \mathrm{P})$ is the most common deformity in maxillofacial region, with incidence ranging from $1 / 700$ to $1 / 1000$ live births worldwide. ${ }^{1,2}$ The incidence of this malformation varies among different populations, the highest incidence in Asian and American population with $1 / 500$ births, followed by European population is $\sim 1 / 1,000$, while African population has the lowest incidence, around $1 / 2,000$ births. ${ }^{1,3,4}$ This incidence in Kinh Vietnamese is published online

February 25, 2022
DOI https://doi.org/ $10.1055 / \mathrm{s}-0041-1733809$ ISSN 0970-0358.

\footnotetext{
(c) 2022. Association of Plastic Surgeons of India. All rights reserved This is an open access article published by Thieme under the terms of the Creative Commons Attribution-NonDerivative-NonCommercial-License, permitting copying and reproduction so long as the original work is given appropriate credit. Contents may not be used for commercial purposes, or adapted, remixed, transformed or built upon. (https://creativecommons.org/ licenses/by-nc-nd/4.0/)

Thieme Medical and Scientific Publishers Pvt. Ltd., A-12, 2nd Floor, Sector 2, Noida-201301 UP, India
} 
$1 / 1,000$. The cause of $\mathrm{CL} / \mathrm{P}$ is complicated, which results from interactions between multiple genetic and environmental risk factors, but to date only $20 \%$ of genetic sensitivity has been identified. ${ }^{5-7}$ Although there are more than 400 mendelian disorders associated with oral clefts and $\mathrm{CL} / \mathrm{P}$ can occur in many malformation syndromes, isolated $\mathrm{CL} / \mathrm{P}$ (nonsyndrome cleft lip with/without palate) constitutes $70 \%$ of all cases. $^{8}$ A genome-wide association study by Beaty et al identified gene variants near MAFB and ABCA4 in $2010 .^{9}$ After that, replication studies from different populations showed confirming evidence, with families of Asian ancestry giving stronger evidence for association with MAFB and $A B C A 4$, but in some different studies, there are conflicting results. ${ }^{9-13}$ $M A F B$ gene encodes the basic leucine zipper transcription factor, which plays an important role in the regulation of hematopoietic cell lines. ${ }^{14}$ It also functions as an oncogene, responsible for the transformation of MAF myeloma cells. ${ }^{15}$ Expression studies support a role for MAFB in palatal development. ${ }^{9}$ Therefore, we conduct this study to evaluate the association between single-nucleotide polymorphisms (SNPs) rs13041247, rs6065259, and rs6072081 of MAFB gene reported by Beaty et al with nonsyndromic cleft lip and palate in Kinh Vietnamese.

\section{Patients and Methods}

\section{Study Population}

We collected saliva from 79 cases with NCL/P deformity at University Medical Center, Ho Chi Minh City and 77 controls of healthy children without this malformation at Children's Hospital I, Ho Chi Minh City for a case-control study. The control selection ensures independence, suitable for age, gender and residence with disease group. Saliva samples that do not qualify for DNA extraction were excluded. In this study, the case samples $(n=79)$ were divided into two subgroups: the group of children with only cleft lip (CLO, $n=29$ ) and the group with cleft lip and cleft palate (CLP, $n=50$ ). We assessed the different effect of target SNPs on the different phenotypes of this malformation.

\section{Saliva Collection, DNA Extraction, and Genotyping}

Unstimulated saliva samples were collected by tampon absorbing the patient's oral mucosa, then put into a test tube containing $5 \mathrm{~mL}$ saline $0.9 \%$, immediately kept on ice and processed within 2 hours. Genomic DNA was extracted using a GeneJet Whole Blood Genomic DNA Purification Mini Kit (ThermoFisher Scientific, Carlsbad, California, United States) according to the manufacturer's instructions. All DNA samples had an A260/A280 ratio of 1.8 to 2.0 and DNA concentration greater than $10 \mathrm{ng} / \mathrm{mL}$.

Target SNPs in MAFB gene were genotyped using tetraARMS PCR technique. ${ }^{16}$ For SNP rs13041247, the components include $0.4 \mu \mathrm{L}$ of $10 \mathrm{mM}$ forward and reverse outer primers, $0.8 \mu \mathrm{L}$ of $10 \mathrm{mM}$ forward and reverse inner primers, $0.1 \mu \mathrm{L}$ Takara Taq HS (Takara Bio, Shiga, Japan), $1.5 \mu \mathrm{L}$ gDNA, $1.5 \mu \mathrm{L}$ of $2.5 \mathrm{mM}$ dNTP, $1.5 \mu \mathrm{L}$ of $10 \mathrm{x}$ buffer, and water up to $15 \mu \mathrm{L}$. The adjusted steps to PCR (conducted on system Mastercyclervapo.protect, Eppendorf) were as follows:
Table 1 The primers for MAFB SNP genotyping by tetra-ARMS PCR technique

\begin{tabular}{|l|l|l|}
\hline SNP & Primers & Prime sequence $\left(\mathbf{5}^{\prime}\right.$-3' $\mathbf{}$ ) \\
\hline rs13041247 & Outer forward & TGGCCTAGTCACAGCTTTGG \\
\cline { 2 - 3 } & Outer reverse & CAGAGAAGACCAGGACTTAG \\
\cline { 2 - 3 } & Inner forward & TTCTTGTACTTCCTGGCGGC \\
\cline { 2 - 3 } & Inner reverse & CTCAGAGATATTAAGTGGCA \\
\hline rs6072081 & Outer forward & ATGGATCTAAGACCAGACAG \\
\cline { 2 - 3 } & Outer reverse & TTGTTGAACCTCCCTAACAG \\
\cline { 2 - 3 } & Inner forward & GCACTGCGTGTGTGACCGAC \\
\cline { 2 - 3 } & Inner reverse & ATTTGGTGCTTATTACCTTA \\
\hline rs6065259 & Outer forward & CAACAGCCTGTCTGGTCTTA \\
\cline { 2 - 3 } & Outer reverse & ATCATTTCATGTGGCGGAGA \\
\cline { 2 - 3 } & Inner forward & TGATTCAGGCTGCTTGGTGT \\
\cline { 2 - 3 } & Inner reverse & ATTTGGTGCTTATTACCCTG \\
\hline
\end{tabular}

Abbreviations: tetra-ARMS PCR, tetra-amplification refractory mutation system polymerase chain reaction; SNP, single-nucleotide polymorphism.

initialization at $98^{\circ} \mathrm{C}$ for 3 minutes, and followed by 40 cycles of three steps: denaturation at $98^{\circ} \mathrm{C}$ for 10 seconds; annealing at $56^{\circ} \mathrm{C}$ for 20 seconds, $72^{\circ} \mathrm{C}$ for 1 minute; extension at $72^{\circ}$ $\mathrm{C}$ for 2 minutes. Primer sequence was displayed in - Table 1.

PCR products were analyzed with $1.5 \%$ agarose gel electrophoresis in TBE $1 \mathrm{X}$ buffer containing ethidium bromide and the genotypes were determined. In SNP rs13041247, 750 bp PCR product was reference fragment, 576 bp when the $C$ allele was present, and $213 \mathrm{bp}$ when the $\mathrm{T}$ allele was present (-Fig. 1A, B). In SNP rs6072081, 275 bp PCR product was reference fragment, $150 \mathrm{bp}$ when the A allele was present, and 164 bp when the G allele was present. In SNP
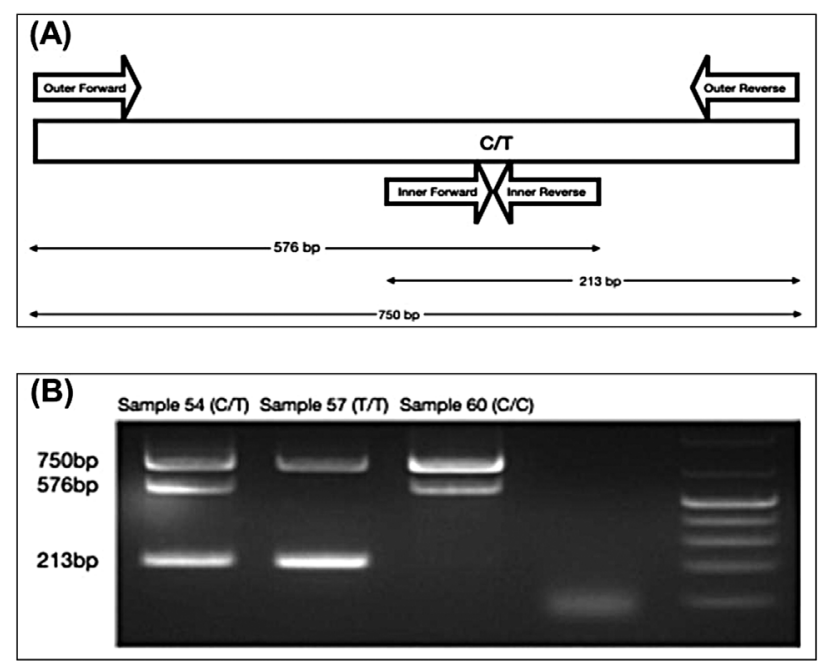

Fig. 1 Schematic illustration of tetra-ARMS PCR assay for SNP rs13041247 genotyping. (A) Location of primers and SNP rs13041247. (B) Agarose gel electrophoresis image of PCR products. $\mathrm{T} / \mathrm{T}$, homozygote for the allele $\mathrm{T} ; \mathrm{C} / \mathrm{C}$, homozygote for the allele $\mathrm{C}$; $C / T$, heterozygote for the alleles $C$ and $T$; SNP, single-nucleotide polymorphism; tetra-ARMS PCR, tetra-amplification refractory mutation system polymerase chain reaction. 
rs6065259, 717 bp PCR product was reference fragment, 584 bp when the A allele was present, 172 bp when the $G$ allele was present.

\section{Statistical Analysis}

We used the chi-squared test to evaluate Hardy-Weinberg equilibrium and difference in allele and genotype frequency between patients and healthy group. Linkage disequilibrium, haplotype analyses, and association analyses of target SNPs were calculated using an online study program. ${ }^{17} \mathrm{~A} p$-value less than 0.05 (two-tailed) was considered statistically significant.

\section{Results}

\section{Distribution of Allele and Genotype Frequencies}

We genotyped target SNPs by tetra-ARMS PCR technique and calculated allele frequency, genotype frequency in patients with different phenotypic subgroups as well as in controls. Odd ratio (OR) with $95 \%$ confidence interval (95\% CI) were calculated to determine the association between MAFB polymorphisms and NCL/P. The rs13041247 and rs6065259 were in Hardy-Weinberg equilibrium $\left(\mathrm{P}_{\text {case }}=0.45\right.$ and $\mathrm{P}_{\text {control }}=0.13$ for rs13041247, $P_{\text {case }}=0.41$ and $P_{\text {control }}=0.3$ for rs6065259),

Table 2 Genotype frequency of MAFB tag SNPs between cases and controls with H-W equilibrium

\begin{tabular}{|c|c|c|c|c|c|c|c|}
\hline \multirow[t]{2}{*}{ SNP } & \multirow[t]{2}{*}{ Genotype } & \multicolumn{2}{|c|}{ Entire cohort } & \multicolumn{2}{|c|}{ Cleft lip only } & \multicolumn{2}{|c|}{ Cleft lip and palate } \\
\hline & & $\begin{array}{l}\text { Cases, } \\
n(\%)\end{array}$ & $\begin{array}{l}\text { Controls, } \\
n(\%)\end{array}$ & $\begin{array}{l}\text { Cases, } \\
n(\%)\end{array}$ & $\begin{array}{l}\text { Controls, } \\
n(\%)\end{array}$ & $\begin{array}{l}\text { Cases, } \\
n(\%)\end{array}$ & $\begin{array}{l}\text { Controls, } \\
n(\%)\end{array}$ \\
\hline \multirow[t]{4}{*}{ rs13041247 } & $\mathrm{T} / \mathrm{T}$ & $36(46)$ & $29(38)$ & $14(48)$ & $29(38)$ & $22(44)$ & $29(38)$ \\
\hline & $\mathrm{C} / \mathrm{T}$ & $32(41)$ & $42(55)$ & $10(34)$ & $42(55)$ & $22(44)$ & $42(55)$ \\
\hline & $\mathrm{C} / \mathrm{C}$ & $11(14)$ & $6(8)$ & $5(17)$ & $6(8)$ & $6(12)$ & $6(8)$ \\
\hline & $\begin{array}{l}\mathrm{H}-\mathrm{W} \text { equilibrium } \\
p \text {-Value }\end{array}$ & 0.45 & 0.13 & 0.23 & 0.13 & 1.00 & 0.13 \\
\hline \multirow[t]{4}{*}{ rs6065259 } & G/G & $42(53)$ & $35(45)$ & $15(52)$ & $35(45)$ & $27(54)$ & $35(45)$ \\
\hline & $\mathrm{G} / \mathrm{A}$ & $29(37)$ & $37(48)$ & $10(34)$ & $37(48)$ & $19(38)$ & $37(48)$ \\
\hline & $A / A$ & $8(10)$ & $5(6)$ & $4(14)$ & $5(6)$ & $4(8)$ & $5(6)$ \\
\hline & $\begin{array}{l}\mathrm{H}-\mathrm{W} \text { equilibrium } \\
p \text {-Value }\end{array}$ & 0.41 & 0.3 & 0.38 & 0.3 & 0.73 & 0.3 \\
\hline \multirow[t]{4}{*}{ rs6072081 } & G/G & $5(6)$ & $13(17)$ & $2(7)$ & $13(17)$ & $3(6)$ & $13(17)$ \\
\hline & $\mathrm{G} / \mathrm{A}$ & $36(46)$ & $50(65)$ & $14(48)$ & $50(65)$ & $22(44)$ & $50(65)$ \\
\hline & $\mathrm{A} / \mathrm{A}$ & $38(48)$ & $14(18)$ & $13(45)$ & $14(18)$ & $25(50)$ & $14(18)$ \\
\hline & $\begin{array}{l}\mathrm{H}-\mathrm{W} \text { equilibrium } \\
p \text {-Value }\end{array}$ & 0.43 & 0.013 & 0.68 & 0.013 & 0.73 & 0.013 \\
\hline
\end{tabular}

Abbreviations: H-W, Hardy-Weinberg; SNP, single-nucleotide polymorphism.

Table 3 Adjusted OR $(95 \% \mathrm{Cl})$ for association between MAFB tag SNPs and CL/P with subgroups

\begin{tabular}{|c|c|c|c|c|c|c|c|}
\hline \multirow[t]{2}{*}{ SNP } & \multirow[t]{2}{*}{ genotype } & \multicolumn{2}{|l|}{ Cleft lip / palate } & \multicolumn{2}{|l|}{ Cleft lip only } & \multicolumn{2}{|l|}{ Cleft lip and palate } \\
\hline & & OR (95\% Cl) & $p$-Value & OR (95\% Cl) & p-Value & OR $(95 \% \mathrm{Cl})$ & p-Value \\
\hline \multirow[t]{4}{*}{ rs13041247 } & $T / T$ & 1.00 (Ref) & \multirow[t]{4}{*}{0.17} & 1.00 (Ref) & \multirow[t]{4}{*}{0.13} & 1.00 (Ref) & \multirow[t]{4}{*}{0.46} \\
\hline & $\mathrm{C} / \mathrm{T}$ & $1.63(0.83-3.19)$ & & $2.03(0.79-5.19)$ & & $1.45(0.68-3.09)$ & \\
\hline & $C / C$ & $0.68(0.22-2.05)$ & & $0.58(0.15-2.23)$ & & $0.76(0.22-2.67)$ & \\
\hline & $\mathrm{C} / \mathrm{T}-\mathrm{C} / \mathrm{C}$ & $1.39(0.73-2.63)$ & & $1.54(0.65-3.66)$ & & $1.30(0.63-2.68)$ & \\
\hline \multirow[t]{4}{*}{ rs6065259 } & G/G & 1.00 (Ref) & \multirow[t]{4}{*}{0.32} & 1.00 (Ref) & \multirow[t]{4}{*}{0.32} & 1.00 (Ref) & \multirow[t]{4}{*}{0.53} \\
\hline & $\mathrm{G} / \mathrm{A}$ & $1.53(0.79-2.97)$ & & $1.59(0.63-4.00)$ & & $1.50(0.71-3.17)$ & \\
\hline & $\mathrm{A} / \mathrm{A}$ & $0.75(0.22-2.50)$ & & $0.54(0.13-2.28)$ & & $0.96(0.24-3.94)$ & \\
\hline & $\mathrm{G} / \mathrm{A}-\mathrm{A} / \mathrm{A}$ & $1.36(0.73-2.56)$ & & $1.29(0.55-3.02)$ & & $1.41(0.69-2.88)$ & \\
\hline \multirow[t]{4}{*}{ rs6072081 } & $\mathrm{A} / \mathrm{A}$ & 1.00 (Ref) & \multirow[t]{4}{*}{$<0.001$} & 1.00 (Ref) & \multirow[t]{4}{*}{0.02} & 1.00 (Ref) & \multirow[t]{4}{*}{$<0.001$} \\
\hline & $G / A$ & $3.77(1.78-7.96)$ & & $3.32(1.27-8.66)$ & & $4.06(1.78-9.25)$ & \\
\hline & G/G & $7.06(2.13-23.42)$ & & $6.04(1.14-32.04)$ & & $7.74(1.88-31.87)$ & \\
\hline & $\mathrm{G} / \mathrm{A}-\mathrm{G} / \mathrm{G}$ & $4.17(2.01-8.64)$ & & $3.66(1.44-9.30)$ & & $4.50(2.02-10.03)$ & \\
\hline
\end{tabular}

Abbreviations: $\mathrm{Cl}$, confidence interval; $\mathrm{CL} / \mathrm{P}$, cleft lip with or without palate; OR, odds ratio; SNP, single-nucleotide polymorphism. 
Table 4 Linkage disequilibrium results between each pair of loci

\begin{tabular}{|l|l|l|}
\hline \multirow{5}{*}{ rs6072081 } & rs6065259 & rs13041247 \\
\cline { 2 - 3 } & 0.146 & 0.140 \\
\hline & 0.812 & 0.664 \\
\cline { 2 - 3 } & 0.655 & 0.603 \\
\cline { 2 - 3 } & 0.429 & 0.364 \\
\cline { 2 - 3 } & $<0.001$ & $<0.001$ \\
\cline { 2 - 3 } & 156 & 156 \\
\hline rs6065259 & $\mathrm{D}$ & 0.158 \\
\cline { 2 - 3 } & $\mathrm{D}^{\text {'a }}$ & 0.817 \\
\cline { 2 - 3 } & $\mathrm{R}$ & 0.726 \\
\cline { 2 - 3 } & $\mathrm{R}^{2 \mathrm{~b}}$ & 0.527 \\
\cline { 2 - 3 } & $p$-Value & $<0.001$ \\
\cline { 2 - 3 } & $\mathrm{N}$ & 156 \\
\hline
\end{tabular}

Abbreviations: SNPs, single-nucleotide polymorphisms. 'D' represents levels of linkage disequilibrium.

${ }^{b} R^{2}$ represents a correlation between two SNPs.

but the other rs6072081 was in disequilibrium with $\mathrm{P}_{\text {control }}$ $=0.013$. The result was similar in CLO and CLP subgroups (-Table 2). As shown in - Table 3, even though the genotype TC of rs13041247 was associated with a trend of cleft lip and palate in Kinh Vietnamese $\left(\mathrm{OR}_{\mathrm{TC} / \mathrm{TT}}=1.63,95 \% \mathrm{CI}=0.83-3.19\right.$, $p=0.17)$, this was not statistically significant $(p>0.05)$. The rs6072081 significantly increased risk of the malformation $\left(\mathrm{OR}_{\mathrm{GG} / \mathrm{AA}}=7.06,95 \% \mathrm{CI}=2.13-23.42, p<0.001\right)$. There was no clear evidence of association between rs6065259 and NCL/P $\left(\mathrm{OR}_{\mathrm{AA} / \mathrm{GG}}=0.75,95 \% \mathrm{CI}=0.22-2.50, p=0.32 ; \mathrm{OR}_{\mathrm{AG} / \mathrm{GG}}=1.53\right.$, $95 \% \mathrm{CI}=0.79-2.97, p=0.32$ ). There was a similar trend between subgroups and controls when the patients were divided into the phenotypic CLO and CLP subgroups for all target SNPs.

\section{Analysis of Haplotype}

Analyses of linkage disequilibrium between target SNPs showed that rs13041247, rs6065259, and rs6072081 were weakly pairwise linked $\left(0.3<R^{2}<0.6\right)$ ( - Table 4$)$. We per- formed haplotype analysis of target SNPs on eight probable haplotype models and found that the risk of developing $\mathrm{NCL} / \mathrm{P}$ was increased by 2.02 times $(\mathrm{OR}=2.02,95 \% \mathrm{CI}=1.07-$ $3.84, p=0.033$ ) with haplotype CAG (-Table 5). Haplotype TGG increased the risk up to 67.22 times (OR $=67.22,95 \%$ $\mathrm{CI}=7.11-635.45, p<0.001)$. The results obtained were statistically significant with $p$-value $<0.05$ and $95 \% \mathrm{CI}>1$.

\section{Discussion}

Saliva sampling for DNA extraction is a less invasive and easier method than taking blood, and tetra-ARMS PCR technique is a low-cost, fast, and reliable method of genotyping that is suitable for developing country conditions. The HardyWeinberg equilibrium analysis showed that rs13041247 and rs6065259 had $p$-values greater than 0.05 in both the case and control groups, indicating that these SNPs had a balanced distribution of genotype and allele frequency in the Kinh Vietnamese population. However, with rs6072081, only the disease group was in Hardy-Weinberg equilibrium, but not in the control group (-Table 2). We found that there were not statistically significant association between rs13041247 and rs6065259 with the malformation. Only with rs6072081, all genotypes other than $\mathrm{G} / \mathrm{G}$ increase the risk of birth defect, and there was a similar significant trend in phenotypic subgroups (-Table 3). These results were clearly different from those of Mi's, Beaty's, and Pan's, and Yuan's, and Fontoura's reports. ${ }^{9,18}$ In Mi's study, rs6065259 was the most important SNP in MAFB, followed by rs $13041247 .{ }^{18}$ In Beaty's study, rs13041247 was the most important SNP and associated with a decreased risk of the birth defect. ${ }^{9}$ In Pan's study, rs13041247 CT, CC, and CT/CC were associated with decreased nonsyndromic orofacial clefts susceptibility, compared with rs13041247 TTwide-type homozygote in a Chinese Han population. ${ }^{12}$ In Yuan's study, marginal associations were detected for rs13041247 of MAFB in the Hispanic dataset, while no association was found for the non-Hispanic white dataset. ${ }^{13}$ In Fontoura's study, no association was found between MAFB and CL/P in Caucasian individuals from Brazil. ${ }^{10}$ This suggests that racial differences may lead to different genetic research results. The results from haplotype model

Table 5 Association between MAFB haplotypes (rs13041247-rs6065259-rs6072081) and CL/P with phenotypic subgroups

\begin{tabular}{|c|c|c|c|c|c|c|c|c|}
\hline \multicolumn{3}{|c|}{ Haplotype } & \multicolumn{2}{|c|}{ Cleft lip with/without palate } & \multicolumn{2}{|l|}{ Cleft lip only } & \multicolumn{2}{|l|}{ Cleft lip and palate } \\
\hline $\mathrm{T}$ & G & A & $\begin{array}{l}\text { OR }(95 \% \mathrm{CI}) \\
1.00\end{array}$ & $\begin{array}{l}p \text {-Value } \\
-\end{array}$ & $\begin{array}{l}\text { OR }(95 \% \mathrm{CI}) \\
1.00\end{array}$ & $\begin{array}{l}p \text {-Value } \\
- \\
\end{array}$ & $\begin{array}{l}\text { OR }(95 \% \mathrm{Cl}) \\
1.00 \\
\end{array}$ & $\begin{array}{l}\text {-Value } \\
-\end{array}$ \\
\hline C & A & G & $2.02(1.07-3.84)$ & 0.03 & $1.98(0.83-4.72)$ & 0.13 & $2.14(1.02-4.51)$ & 0.05 \\
\hline$T$ & $G$ & G & $67.22(7.11-635.45)$ & $<0.001$ & $22.40(2.35-213.57)$ & 0.01 & $116 \times 10^{9}$ & $<0.001$ \\
\hline C & G & A & $0.92(0.25-3.41)$ & 0.90 & $0.97(0.17-5.38)$ & 0.97 & $0.94(0.22-4.01)$ & 0.94 \\
\hline C & G & G & $2.94(0.68-12.69)$ & 0.15 & $2.45(0.36-16.83)$ & 0.36 & $3.34(0.64-17.29)$ & 0.15 \\
\hline $\mathrm{T}$ & A & G & $0.27(0.01-8.82)$ & 0.47 & $0.29(0.01-7.35)$ & 0.45 & $0.77(0.04-16.12)$ & 0.87 \\
\hline C & $A$ & A & $1.01(0.19-5.42)$ & 0.99 & $0.84(0.14-4.89)$ & 0.84 & $1.42(0.15-13.11)$ & 0.76 \\
\hline $\mathrm{T}$ & $A$ & $A$ & $8.04(0.39-165.61)$ & 0.18 & $2.61(0.13-51.39)$ & 0.53 & - & - \\
\hline
\end{tabular}

Abbreviations: $\mathrm{Cl}$, confidence interval; $\mathrm{CL} / \mathrm{P}$, cleft lip with or without palate; OR, odds ratio. 
analysis of target SNPs showed a significant increase in risk compared with individual analysis of those. This indicates that SNPs can affect the birth defect following the polygenic genetic model and that risk factor for haplotype analysis was much higher than when assessing the individual effects of each target SNP. There was a similar result when the cases were divided into the phenotypic subgroups (-Table 5).

\section{Conclusions:}

In conclusion, although our study is limited by sample size, the results provided preliminary evidences of the association of MAFB polymorphism with NCL/P in Kinh Vietnamese. The results of the study have contributed to understanding of the genetic factors of maxillofacial congenital malformation in Vietnamese children, as well as facilitating the implementation of molecular biology techniques in the condition of Vietnam. In the future, we will conduct more research on the genetic factors and genetic-environment correlation of the most common orofacial birth defect, which currently only $20 \%$ of genetic sensitivity has been identified.

\section{Ethics Statement}

The study was reviewed and approved by the Ethics Committee of University of Medicine and Pharmacy at Ho Chi Minh City. Each participant provided informed consent before enrolling in the study.

\section{Conflict of Interest}

None declared.

\section{References}

1 Mossey PA, Little J, Munger RG, Dixon MJ, Shaw WC. Cleft lip and palate. Lancet 2009;374(9703):1773-1785

2 Murray JC. Gene/environment causes of cleft lip and/or palate. Clin Genet 2002;61(04):248-256

3 Christensen K, Mitchell LE. Familial recurrence-pattern analysis of nonsyndromic isolated cleft palate-a Danish Registry study. Am J Hum Genet 1996;58(01):182-190
4 Stanier P, Moore GE. Genetics of cleft lip and palate: syndromic genes contribute to the incidence of non-syndromic clefts. Hum Mol Genet 2004;13(Spec No 1):R73-R81

5 Carinci F, Scapoli L, Palmieri A, Zollino I, Pezzetti F. Human genetic factors in nonsyndromic cleft lip and palate: an update. Int J Pediatr Otorhinolaryngol 2007;71(10):1509-1519

6 Mitchell LE, Risch N. Mode of inheritance of nonsyndromic cleft lip with or without cleft palate: a reanalysis. Am J Hum Genet 1992;51(02):323-332

7 Vieira AR. Unraveling human cleft lip and palate research. J Dent Res 2008;87(02):119-125

8 Sivertsen A, Wilcox AJ, Skjaerven R, et al. Familial risk of oral clefts by morphological type and severity: population based cohort study of first degree relatives. BMJ 2008;336(7641):432-434

9 Beaty TH, Murray JC, Marazita ML, et al. A genome-wide association study of cleft lip with and without cleft palate identifies risk variants near MAFB and ABCA4. Nat Genet 2010;42(06):525-529

10 Fontoura C, Silva RM, Granjeiro JM, Letra A. Further evidence of association of the ABCA4 gene with cleft lip/palate. Eur J Oral Sci 2012;120(06):553-557

11 Lennon CJ, Birkeland AC, Nuñez JAP, et al. Association of candidate genes with nonsyndromic clefts in Honduran and Colombian populations. Laryngoscope 2012;122(09):2082-2087

12 Pan Y, Zhang W, Du Y, et al. Different roles of two novel susceptibility loci for nonsyndromic orofacial clefts in a Chinese Han population. Am J Med Genet A 2011;155A(09):2180-2185

13 Yuan Q Blanton SH, Hecht JT. Association of ABCA4 and MAFB with non-syndromic cleft lip with or without cleft palate. Am J Med Genet A 2011;155A(06):1469-1471

14 Gemelli C, Montanari M, Tenedini E, et al. Virally mediated MafB transduction induces the monocyte commitment of human CD34+ hematopoietic stem/progenitor cells. Cell Death Differ 2006;13(10):1686-1696

15 van Stralen E, van de Wetering M, Agnelli L, Neri A, Clevers HC, Bast BJ. Identification of primary MAFB target genes in multiple myeloma. Exp Hematol 2009;37(01):78-86

16 Medrano RFV, de Oliveira CA. Guidelines for the tetra-primer ARMS-PCR technique development. Mol Biotechnol 2014;56(07): 599-608

17 SNPStats. Institut Català d'Oncologia. Accessed April 9, 2021 from URL: http://bioinfo.iconcologia.net/snpstats/start.htm

18 Mi N, Hao Y, Jiao X, et al. Association study of single nucleotide polymorphisms of MAFB with non-syndromic cleft lip with or without cleft palate in a population in Heilongjiang Province, northern China. Br J Oral Maxillofac Surg 2014;52(08):746-750 